\title{
Financial Implications of Early Tracheostomy in the Healthcare Cost Containment Era
}

\author{
${ }^{1}$ Bernardino Branco, ${ }^{2}$ Joseph De Vitis, ${ }^{3}$ Bellal Joseph, ${ }^{4}$ Narong Kulvatunyou, ${ }^{5}$ Andy Tang \\ ${ }^{6}$ Randall S Friese, ${ }^{7}$ Peter Rhee, ${ }^{8}$ Terence O'Keeffe
}

\begin{abstract}
Background: Tracheostomy is often performed for critically ill patients who are anticipated to have a prolonged intensive care unit (ICU) stay, in order to prevent the complications of endotracheal intubation. The timing of a tracheostomy has been much studied over the past 40 years with many analyses differing in methodology, patient population and outcomes. The purpose of this study was to investigate if early tracheostomy ( $\leq 7$ days) in critically ill trauma patients increase ventilator and ICU-free days, reduce hospital days and decrease hospital costs.
\end{abstract}

Materials and methods: Trauma patients admitted to a level 1 Trauma Center requiring tracheostomy (2006-2013) were retrospectively identified. Patients receiving early tracheostomy ( $\leq 7$ days) were compared to late tracheostomy ( $>7$ days) for demographics, clinical data and outcomes. Dichotomous variables were compared by Chi-square or Fisher's exact tests, where appropriate, and continuous variables were compared using Student's t or Mann-Whitney U tests.

Results: Five hundred and twenty-nine patients required a tracheostomy during the study period [292 (55.2\%) early and $237(44.8 \%)$ late]. Patients requiring early tracheostomy were more often male $(80.5$ vs $70.5 \%, p=0.007)$ and younger $(41.5 \pm$ 18.6 years vs $50.5 \pm 21.2$ years, $p<0.001)$. There were no differences in injury severity scores (ISS $28.4 \pm 12.5$ vs $27.2 \pm$ $11.1, p=0.161$ ) but early tracheostomy patients were more likely to sustain severe traumatic brain injury (81.2 vs $65.0 \%$, $p<0.001)$. There were no differences in transfusion requirements or need for intracavitary procedures. When outcomes were analyzed, while there was no difference in mortality ( 8.9 vs $5.1 \%$, adjusted $p=0.126)$, early tracheostomy patients had significantly shorter ventilator days ( $8.7 \pm 7.2$ days vs $19.0 \pm 10.4$ days, adjusted $p<0.001)$, hospital days $(22.3$ \pm 17.9 days vs $30.0 \pm 18.4$ days, adjusted $p<0.001)$ and ICU days (11.6 \pm 8.4 days vs $22.8 \pm 11.6$ days, adjusted $p<0.001)$. In addition, ventilator-associated pneumonia rates were lower among early tracheostomy patients (8.6 vs $17.7 \%$, adjusted $p=0.002$ ). Hospital costs were unsurprisingly less in early tracheostomy patients $(\$ 55,371 \pm 36,280$ vs $\$ 93,702 \pm 51,427$, adjusted $p<0.001$ ).

\footnotetext{
${ }^{1}$ Chief Resident, ${ }^{2}$ Intern, ${ }^{3-5,8}$ Associate Professor

${ }^{6,7}$ Professor

${ }^{1-8}$ Department of Surgery, University of Arizona, USA
}

Corresponding Author: Terence O'Keeffe, Associate Professor, Department of Surgery, University of Arizona, USA Phone: 5206260064, e-mail: tokeeffe@surgery.arizona.edu
Conclusion: In critically, ill trauma patients, early tracheostomy was associated with shorter duration of mechanical ventilation, ICU and hospital days, and lower ventilation associated pneumonia rates. In addition, total hospital costs were significantly decreased in the early tracheostomy group. In this cohort alone, early tracheostomy would have resulted in a potential hospital cost saving of 2.5 million/year.

Keywords: Brain injuries, Costs and cost analysis, Critical illness, Length of stay, Outcome research, Pneumonia, Ventilator-associated, Tracheostomy.

How to cite this article: Branco B, De Vitis J, Joseph B, Kulvatunyou N, Tang A, Friese RS, Rhee P, O'Keeffe T. Financial Implications of Early Tracheostomy in the Healthcare Cost Containment Era. Panam J Trauma Crit Care Emerg Surg 2015;4(3):194-201.

\section{Source of support: Nil}

\section{Conflict of interest: None}

\section{RESUMEN}

Introducción: En general, las traqueotomías son performadas en enfermos críticos en quienes se anticipa una prolongada estadía en la unidad de cuidados intensivos (UTI) previniendo así complicaciones relacionadas a la intubación endotraqueal. En los últimos 40 años se ha estudiado el mejor momento para perfomar traqueotomías, con análisis que difieren en su metodología, demografía y resultados. El objetivo de este estudio fue investigar si la traqueotomía temprana ( $<7$ días) en los pacientes de trauma gravemente enfermos aumentan días en respirador, días fuera de la UTI, reduce días de hospitalización y costos hospitalarios.

Materiales y métodos: Los pacientes con trauma admitidos en un centro de trauma nivel 1 que requirieron traqueotomías (2006-2013) fueron identificados retrospectivamente. Se compararon la demografía, datos clínicos y resultados de los pacientes que recibieron la traqueotomía temprana ( $\leq 7$ días) con traqueotomía tardía ( $>7$ días). Variables dicotómicas se compararon mediante Chi-cuadrado o método de Fisher, en su caso, y se compararon las variables continuas mediante el t-Student o el U-test de Mann-Whitney.

Resultados: quinientos veintinueve pacientes requirieron una traqueotomía durante el período de estudio [292 (55,2\%) temprana y $237(44,8 \%)$ tardía]. Los pacientes que requirieron traqueotomía temprana fueron con mayor frecuencia varones $(80,5$ vs $70,5 \%, p=0,007)$ y más jóvenes $(41,5 \pm 18,6$ años frente a $50,5 \pm 21,2$ años, $p<0,001)$. No había diferencias en las puntuaciones de gravedad de lesiones (ISS $28,4 \pm 12,5 \mathrm{vs}$ $27,2 \pm 11,1, p=0,161$ ), pero los pacientes con traqueotomía tempranas eran más comúnmente aquellos que sufrieron una

Paper presented in Resident Research Competition in PTS Congress, Panama City, Panama, Nov 2014. 
lesión cerebral traumática grave $(81,2$ vs $65,0 \%, p<0,001)$. No hubo diferencias en los requisitos de transfusión sanguínea o necesidad de procedimientos intracavitarios. Cuando se analizaron los resultados, mientras que no hubo diferencia en mortalidad ( 8,9 vs $5,1 \%, p=0,126$ ajustado), los pacientes con traqueotomía temprana tuvieron menos días de uso de ventilación mecánica $(8,7 \pm 7,2$ días vs 19,0 \pm 10,4 días, p ajustado $<0,001)$, menos días de hospitalización $(22,3 \pm$ 17,9 días frente a $30,0 \pm 18,4$ días, $p$ ajustado $<0,001$ ) y menos días en la UTI $(11,6 \pm 8,4$ días frente a $22,8 \pm 11,6$ días, $\mathrm{p}$ ajustado $<0,001)$.

Conclusión: En pacientes post trauma, críticamente enfermos, la traqueotomía temprana se asoció con una menor duración de la ventilación mecánica, menos días en la UTI y el hospital, así también como una menor tasa de neumonía asociada a la ventilación mecánica. Además, los costos hospitalarios totales fueron significativamente menores en el grupo de traqueotomía temprana. En solo esta cohorte, la traqueotomía temprana habría dado lugar a un potencial ahorro de costos hospitalarios de 2,5 millones de dólares anuales.

Palabras claves: Costos y analisis de costos, Enfermos criticos, Investigacion de resultados, Lesiones cerebrales, Neumocia asociada a ventilación mecanica, Tiempo de estadia, Traqueostomia.

\section{INTRODUCTION}

Tracheostomy is often performed for critically ill patients who are anticipated to have a prolonged intensive care unit (ICU) stay, in order to prevent the complications of long-term endotracheal intubation. ${ }^{1,2}$ The optimal timing of tracheostomy has been much debated over the past 40 years. $^{2}$ The available studies regarding this issue vary in methodology, patient population, and study outcome measures. ${ }^{3}$ Controversy also surrounds differentiating those patients who will require prolonged ventilation, and would, therefore, ultimately benefit from the procedure. As a consequence, the timing of tracheostomy has become individualized, giving rise to the term the 'anticipatory approach' ${ }^{4,5}$ During the American Consensus Conference on Artificial Airways in 1989, a guideline was established stating that 'for anticipatory need of the artificial airway greater than 21 days, tracheotomy is preferred'. ${ }^{4}$

After the consensus report, research began to emerge suggesting that an early tracheostomy may be beneficial in trauma patients. ${ }^{6,7}$ However, a recent systematic review of the literature by Dunham et al showed no difference in outcomes between early and late tracheostomy in trauma patients; despite this, the meta-analysis suggested that early tracheostomy was associated with a decrease in ventilator and ICU days for patients with severe head trauma, and that further research was needed. ${ }^{8}$ For patients suffering from traumatic brain injury (TBI) specifically, prolonged intubation and ventilatory support is frequently required due to inadequate spontaneous ventilation, inability to maintain an adequate airway due to conscious level, and difficulty clearing excessive secretions. ${ }^{9}$ To date, only a small number of studies have investigated the outcome of early tracheostomy for TBI patients specifically, all of which widely vary in methodology and suffer from small sample sizes. ${ }^{10-13}$

Further research is, therefore, warranted in a larger cohort of patients to investigate if early tracheostomy can improve outcomes for trauma patients. The purpose of this study was to investigate if early tracheostomy ( $\leq 7$ days) could be of benefit in critically ill trauma patients, particularly in those with TBI. Our hypothesis was that early tracheostomy would increase ventilatorfree and ICU free days, reduce hospital length of stay and consequently decrease hospital costs.

\section{MATERIALS AND METHODS}

After institutional review board approval, all trauma patients admitted to the University of Arizona Medical Center (UMC) from 1st Jan 2006 to Dec 31st 2013 were retrospectively reviewed. Patient variables were extracted including age, gender, mechanism of injury, intubation requirements, admission vitals, Glasgow coma scale (GCS), injury severity score (ISS), associated injuries, procedures required, complications, such as ventilator associated pneumonia and acute renal failure, ventilation days, ICU LOS, hospital LOS, hospital costs and mortality. In addition, hospital charges, costs and reimbursements were also extracted. Patients receiving early tracheostomy ( $\leq 7$ days) were compared to late tracheostomy ( $>7$ days). Continuous variables were dichotomized using the following clinically relevant cut-points: age ( $\geq 55 \mathrm{vs}$ $<55)$, respiratory rate on admission ( $<10$ or $>24$ vs $\geq 10$ or $\leq 24$ breaths/min), systolic blood pressure (SBP) on admission $(<90 v s \geq 90 \mathrm{~mm} \mathrm{Hg})$, GCS on admission $(\leq 8$ $v s>8)$, and ISS ( $\geq 16$ vs $<16)$.

Dichotomous variables were compared utilizing Chi-square or Fisher's exact tests whereas continuous variables were compared utilizing unpaired Student's t or Mann-Whitney $U$ tests. The summary data is presented as a raw percentage or mean $\pm \mathrm{SD}$. The $\mathrm{p}$-values were significantly different at $\mathrm{p}<0.05$.

The primary outcome measures of this study were ventilation days and hospital costs. Secondary outcome measures were mortality, HLOS, ICU LOS, complications, hospital charges and reimbursements. Logistic regression modeling was performed to control for confounders that were significantly different at the $\mathrm{p}<0.05$ level among the groups. Values are reported as means \pm standard deviation (SD); median (range) for continuous variables and as percentage for categorical variables. All analysis were performed using the Statistical Package for Social 
Sciences (SPSS Mac), version 22.0 (SPSS Inc, Chicago, IL, USA).

\section{RESULTS}

During the 8-year study period, a total of 529 patients required a tracheostomy. Of those, 292 (55.2\%) underwent early tracheostomy ( $\leq 7$ days) and $237(44.8 \%)$ late tracheostomy ( $>7$ days). Patients requiring early tracheostomy were more likely to be male (80.5 vs $70.5 \%, \mathrm{p}=0.007)$ and younger ( $41.5 \pm 18.6$ years vs $50.5 \pm$ 21.2 years, $\mathrm{p}<0.001)$. There were no differences in ISS ( $28.4 \pm 12.5$ vs $27.2 \pm 11.1, \mathrm{p}=0.161$ ) but early tracheostomy patients were more likely to sustain severe traumatic brain injury (Head AIS $\geq 3: 81.2$ vs $65.0 \%, \mathrm{p}<0.001$ ). There were no differences in $\mathrm{pRBC}$ requirements or need for intracavitary procedures (Table 1).

When outcomes were analyzed, hospital charges and reimbursements were also lower in the early tracheostomy group (Table 2). There was no difference in mortality ( 8.9 vs $5.1 \%$, adjusted $\mathrm{p}=0.126$ ), early tracheostomy patients had significantly shorter ventilator days $(8.7 \pm$ 7.2 days vs $19.0 \pm 10.4$ days, adjusted $\mathrm{p}<0.001)$, hospital LOS (22.3 \pm 17.9 days vs $30.0 \pm 18.4$ days, adjusted $\mathrm{p}<$ $0.001)$ and ICU LOS (11.6 \pm 8.3 days vs $22.8 \pm 11.6$ days, adjusted $\mathrm{p}<0.001)$. Hospital costs were also lower in early tracheostomy patients $(\$ 55,371 \pm 36,280$ vs $\$ 93,702 \pm$

Table 1: Demographic and clinical data of patient groups

\begin{tabular}{|c|c|c|c|c|}
\hline & $\begin{array}{l}\text { Total } \\
(n=529)\end{array}$ & $\begin{array}{l}\text { Early tracheostomy } \\
(\leq 7 \text { d) }(n=292)\end{array}$ & $\begin{array}{l}\text { Late tracheostomy } \\
(>7 \text { d) }(n=237)\end{array}$ & $p$-value \\
\hline Age (y), mean \pm SD; (median) (range) & $\begin{array}{l}45.5 \pm 20.2 ;(46) \\
(4-91)\end{array}$ & $\begin{array}{l}41.5 \pm 18.6 ;(40) \\
(7-87)\end{array}$ & $\begin{array}{l}50.5 \pm 21.2 ;(52) \\
(4-91)\end{array}$ & $<0.001^{*}$ \\
\hline Age $\geq 55(\%)$ & $35.0 \%(185)$ & $27.4 \%(80)$ & $44.3 \%(105)$ & $<0.001^{*}$ \\
\hline Male $(\%)$ & $76.0 \%(402)$ & $80.5 \%(235)$ & $70.5 \%(167)$ & $0.007^{*}$ \\
\hline Blunt $(\%)$ & $88.1 \%(466)$ & $83.2 \%(243)$ & $94.1 \%(223)$ & $<0.001^{*}$ \\
\hline Intubated on admission (\%) & $92.7 \%(471)$ & $93.9 \%(263)$ & $91.2 \%(208)$ & 0.244 \\
\hline SBP on admission, mean \pm SD; (median) (range) & $\begin{array}{l}135.1 \pm 33.8 \\
(137)(0-273)\end{array}$ & $\begin{array}{l}134.9 \pm 34.5 ;(137) \\
(0-245)\end{array}$ & $\begin{array}{l}135.1 \pm 33.1 ;(136) \\
(58-273)\end{array}$ & 0.614 \\
\hline SBP on admission $<90 \mathrm{~mm} \mathrm{Hg} \mathrm{( \% )}$ & $7.6 \%(40)$ & $7.5 \%(22)$ & $7.6 \%(18)$ & 0.979 \\
\hline GCS on admission $\leq 8(\%)$ & $53.9 \%(285)$ & $65.8 \%(192)$ & $39.2 \%(93)$ & $<0.001^{*}$ \\
\hline pRBC transfusion $(\%)$ & $48.8 \%(258)$ & $43.8 \%(128)$ & $54.9 \%(130)$ & $0.012^{*}$ \\
\hline Massive transfusion protocol activated (\%) & $3.8 \%(20)$ & $1.7 \%(5)$ & $6.3 \%(15)$ & $0.006^{*}$ \\
\hline ISS, mean \pm SD; (median) (range) & $\begin{array}{l}27.8 \pm 11.8 ;(27) \\
(1-75)\end{array}$ & $\begin{array}{l}28.4 \pm 12.5 ;(27) \\
(1-75)\end{array}$ & $\begin{array}{l}27.2 \pm 11.1 ;(27) \\
(1-66)\end{array}$ & 0.161 \\
\hline ISS $\geq 16(\%)$ & $83.9 \%(443)$ & $84.2 \%(246)$ & $83.5 \%(197)$ & 0.810 \\
\hline Head AIS $\geq 3(\%)$ & $73.9 \%(391)$ & $81.2 \%(237)$ & $65.0 \%(154)$ & $<0.001^{*}$ \\
\hline Chest AIS $\geq 3(\%)$ & $40.1 \%(212)$ & $34.9 \%(102)$ & $46.4 \%(110)$ & $0.007^{*}$ \\
\hline Abdomen AIS $\geq 3(\%)$ & $12.3 \%(65)$ & $4.8 \%(14)$ & $21.5 \%(51)$ & $<0.001^{*}$ \\
\hline Craniotomy/craniectomy (\%) & $14.2 \%(75)$ & $15.1 \%(44)$ & $13.1 \%(31)$ & 0.441 \\
\hline Thoracotomy $(\%)$ & $3.2 \%(17)$ & $2.1 \%(6)$ & $4.6 \%(11)$ & 0.093 \\
\hline Laparotomy (\%) & $18.1 \%(96)$ & $13.0 \%(38)$ & $24.5 \%(58)$ & $0.002^{*}$ \\
\hline
\end{tabular}

The $p$-values for categorical variables were derived from Chi-square or Fisher's exact tests; $p$-values for continuous variables were derived from unpaired Student's t or Mann-Whitney U tests; ${ }^{*} p$-values are significantly different $(p<0.05)$; SD: Standard deviation; SBP: Systolic blood pressure; GCS: Glasgow coma scale score; pRBC: Packed red blood cell; ISS: Injury severity score; AIS: Abbreviated injury scale

Table 2: Financial and length of stay data

\begin{tabular}{|c|c|c|c|c|}
\hline & $\begin{array}{l}\text { Mean } \pm S D ; \\
\text { (median) (range) }\end{array}$ & $\begin{array}{l}\text { Mean } \pm S D ; \\
\text { (median) (range) }\end{array}$ & $\begin{array}{l}\text { Mean } \pm S D ; \\
\text { (median) (range) }\end{array}$ & $p$-value \\
\hline Hospital charges $(\$)$ & $\begin{array}{l}271,690 \pm 173,405 \\
(231,912)(118-1,254,708)\end{array}$ & $\begin{array}{l}209,075 \pm 129,165 \\
(182,483)(118-977,872)\end{array}$ & $\begin{array}{l}348,011 \pm 189,415 \\
(289,282)(95,860- \\
1,254,708)\end{array}$ & $<0.001^{*}$ \\
\hline Hospital costs $(\$)$ & $\begin{array}{l}72,781 \pm 47,755 ;(60,534) \\
(11-318,705)\end{array}$ & $\begin{array}{l}55,371 \pm 36,280 ;(49,433) \\
(11-318,705)\end{array}$ & $\begin{array}{l}93,702 \pm 51,427 ;(78,467) \\
(23,596-316,160)\end{array}$ & $<0.001^{*}$ \\
\hline Hospital reimbursements $(\$)$ & $\begin{array}{l}79,096 \pm 57,523 ;(67,863) \\
(205-320,941)\end{array}$ & $\begin{array}{l}61,876 \pm 51,808 ;(49,587) \\
(205-320,050)\end{array}$ & $\begin{array}{l}98,627 \pm 57,601 ;(87,776) \\
(308-320,941)\end{array}$ & $<0.001^{*}$ \\
\hline Ventilation days & $13.3 \pm 10.1 ;(11)(1-80)$ & $8.7 \pm 7.2 ;(7)(1-53)$ & $19.0 \pm 10.4 ;(16),(2-80)$ & $<0.001^{*}$ \\
\hline ICU days & $16.7 \pm 11.4 ;(14)(1-92)$ & $11.6 \pm 8.3 ;(10)(1-52)$ & $22.8 \pm 11.6 ;(20),(5-92)$ & $<0.001^{*}$ \\
\hline Hospital days & $25.8 \pm 18.6 ;(22)(1-154)$ & $22.3 \pm 17.9 ;(17)(1-123)$ & $30.0 \pm 18.4 ;(25),(10-154)$ & $<0.001^{*}$ \\
\hline
\end{tabular}

The $p$-values were derived from multivariable analysis; The $p$-values were obtained after adjustment for demographics and clinical data; ${ }^{*} p$-values are significantly different $(p<0.05)$; ICU: Intensive care unit 
Table 3: Mortality, complications and disposition

\begin{tabular}{lllll}
\hline & $\begin{array}{l}\text { Total } \\
(n=529)\end{array}$ & $\begin{array}{l}\text { Early tracheostomy } \\
(\leq 7 d)(n=292)\end{array}$ & $\begin{array}{l}\text { Late tracheostomy } \\
(>7 d)(n=237)\end{array}$ & $\begin{array}{l}\text { Adjusted } \\
p \text {-value }\end{array}$ \\
\hline Mortality (\%) & $7.2 \%(38)$ & $8.9 \%(26)$ & $5.1 \%(12)$ & 0.126 \\
VAP (\%) & $12.7 \%(67)$ & $8.6 \%(25)$ & $17.7 \%(42)$ & $0.002^{*}$ \\
ARF (\%) & $4.0 \%(21)$ & $1.7 \%(5)$ & $6.8 \%(16)$ & $0.003^{*}$ \\
Unintentional extubation with reintubation (\%) & $7.4 \%(39)$ & $1.7 \%(5)$ & $14.3 \%(34)$ & $<0.001^{*}$ \\
Discharge home or SNF (\%) & $37.6 \%(199)$ & $39.0 \%(114)$ & $35.9 \%(85)$ & 0.453 \\
\hline
\end{tabular}

The $p$-values were derived from bivariate analysis; The p-values were obtained after adjustment for demographics and Clinical data; ${ }^{*} p$-values are significantly different $(p<0.05)$; VAP: Ventilator associated pneumonia; ARF: Acute renal failure; SNF: Skilled nursing facility
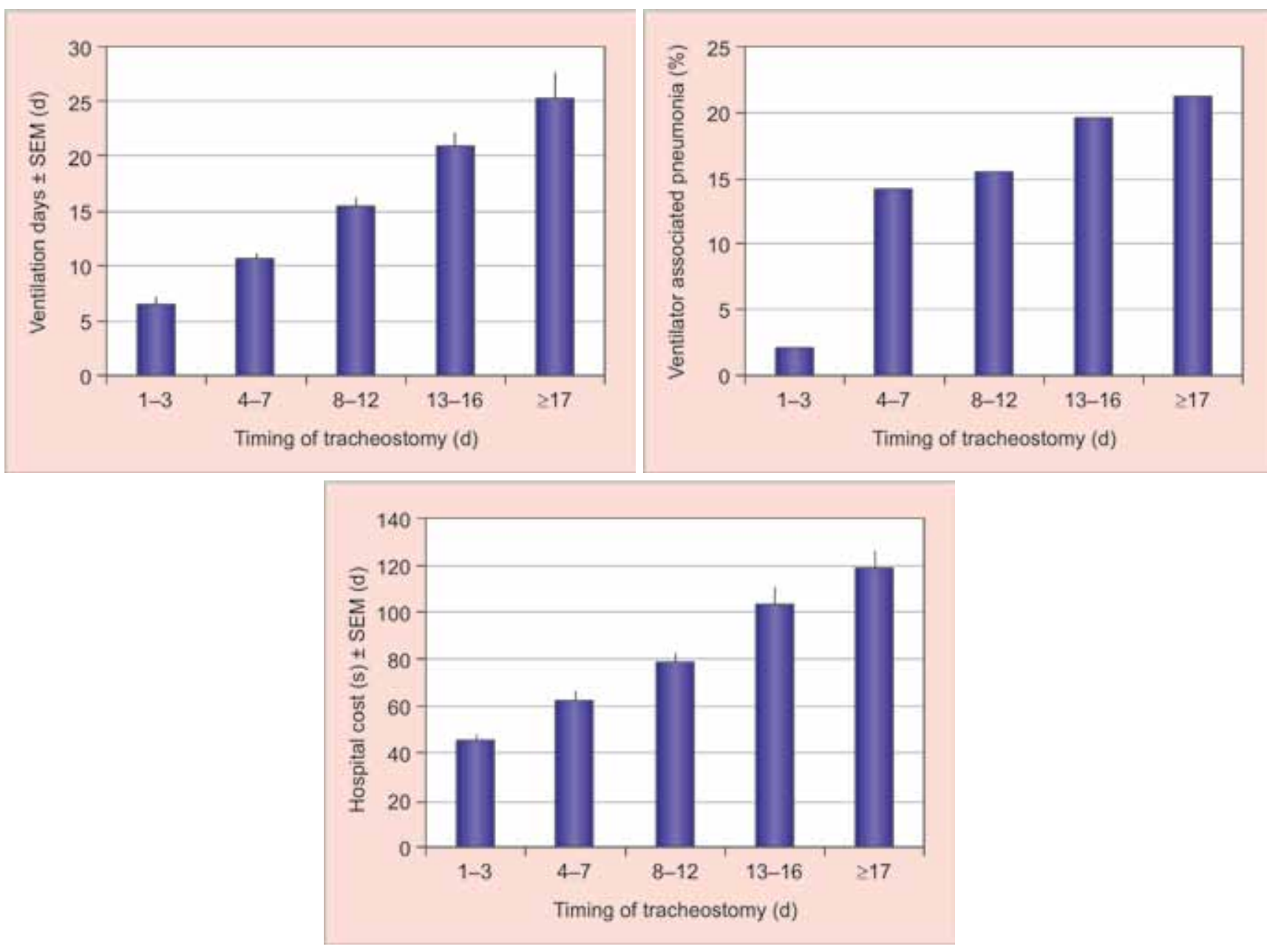

Graph 1: Timing of tracheostomy and outcomes

51,427 , adjusted $\mathrm{p}<0.001$ ) (Table 3). In addition, ventilator associated pneumonia rates were also lower among early tracheostomy patients (8.6 vs $17.7 \%$, adjusted $\mathrm{p}=0.002)$.

Graph 1 depicts the relationship between the time of tracheostomy and ventilation days, ventilator associated pneumonia rates and hospital costs. There was a stepwise increase in these outcomes as timing of tracheostomy increased.

\section{DISCUSSION}

Our findings demonstrate that patients receiving an early tracheostomy ( $\leq 7$ days) not only positively affect the clinical outcomes for the patient, but also demonstrate economic benefits for patients and hospitals. The early tracheostomy group spent significantly less time in the ICU, less time on mechanical ventilation, an overall decreased LOS in the hospital, and lowered costs and charges for both the patient and the hospital. The data was also consistent with other studies in demonstrating no significant effect on mortality to the patient. ${ }^{14,15}$

Early tracheostomy has been reported to decrease the amount of time spent on mechanical ventilation, require less sedation, and lower ICU and overall hospital LOS. ${ }^{16,17}$ The study by Alali et al included a cohort of adults with isolated TBI who underwent tracheostomy within one of 135 participating centers in the American College 
of Surgeons' Trauma Quality Improvement Program, during 2009 to 2011. They used propensity matching to compare patients who underwent early ( $\leq 8$ days) vs late ( $>8$ days) tracheostomy. They were able to demonstrate that early tracheostomy was associated with a shorter duration of mechanical ventilation, ICU stay, and hospital stay. ${ }^{16}$ Our data is consistent with these previous findings. In our analysis, early tracheostomy decreased mean ventilator days by $50 \%$, decreased ICU LOS by 11 days, and overall hospital LOS by 7 days. While in this study, we have defined early tracheostomy to be $\leq 7$ days, the exact timing of tracheostomy can also significantly impact ventilator days and hospital costs (Graph 1). Patients who received a tracheostomy within 3 days of admission benefited from decreased days on ventilation and decreased associated hospital costs. An apparent linear association is also demonstrated as the length of time increases from performing a tracheostomy to ventilator days and hospital costs. However, as stated above, no clinical guidelines exist as to predict a patient's need for tracheostomy based on presenting injuries or clinical factors. Previous studies that have attempted to predict the necessity of tracheostomy in ventilated patients have not been universally accepted. ${ }^{18}$ Therefore, if a patient's anticipated ventilator course will require more than 21 days of endotracheal intubation, we suggest that a tracheostomy be performed as soon as possible in order to capitalize on the observed benefits of this study.

The association between tracheostomy and ventilatorassociated pneumonia (VAP) has been studied quite extensively. Some studies have suggested that tracheostomy may be associated with higher rates of $\mathrm{VAP}_{1}^{18,19}$ while others have pointed to tracheostomy as an independent risk factor for the development of VAP. ${ }^{20-23}$ However, many of these studies are limited in design or fail to examine the exact timing of tracheostomy. More recently, studies have found early tracheostomy was associated not only with shorter mechanical ventilation days, ICU and hospital LOS, but also decreased rates of VAP. ${ }^{24-26}$ Our results are consistent with these findings in that more than $50 \%$ of late tracheostomy patients (ET $8.6 v \mathrm{~s}$ LT 17.7\%) developed VAP. However, when looking at the exact timing of each patient's tracheostomy, only the group who received a tracheostomy within the first 3 days of admission demonstrated significantly lower rates of VAP. Subsequent groups were still able to benefit slightly from an earlier tracheostomy. Regardless, our data is consistent with other papers that have been published on this same topic.

While this clinical data reinforces the positive consequences of performing early tracheostomy, the more important and relevant conclusion that can be drawn from this study is financial gain that both the patient and hospital can benefit from. In our cohort study of 529 patients, the 292 patients that received early tracheostomy saved a mean total of $\$ 138,936$ in hospital charges due to LOS reduction. Hospitals also saved \$38,331 from performing an early tracheostomy mainly due to less time using mechanical ventilation, smaller amounts of sedative medications, and reduced costs in airway hygienic maintenance. If all the patients within our cohort received early tracheostomy, it is estimated that up to $\$ 2.5$ million/ year could have been saved in hospital costs.

Our study is not without its limitations. First and foremost, this is a retrospective analysis, and thus unknown confounding variables may exist within the data set that we were unable to control for. The age distribution between early and late tracheostomy is significant in that patients $>55$ years of age were more likely to receive a late tracheostomy. Due to our study being retrospective in nature, it can only be postulated that the decision to delay tracheostomy placement was influenced by the patient's age and if the patient was less likely to tolerate the procedure. The patients who did receive early tracheostomy were younger than 55 years of age and could conceivably respond better to the procedure. The majority of patients who received an early tracheotomy also had certain clinical factors at the time of presentation that most likely influenced whether a tracheostomy was performed immediately or not. Most patients who received an early tracheostomy had a GCS score of $<8$ and had significant head, chest, and abdominal injuries. While this makes our results more difficult to generalize to all trauma patients, it does highlight that recognizing critically ill patients as potential early tracheostomy recipients can have important benefits. Finally, while our study has demonstrated decreased rates of VAP, these rates can differ significantly between various ICUs due to varying protocols, staff, and other unknown differences that could potentially affect the development of VAP.

Overall, our study has been able to not only reinforce the positive clinical outcomes when performing a tracheostomy within the first 7 days of admission for critically ill trauma patients, but also the economical and financial implications that this procedure can have on hospitals' and patients' healthcare costs. Future prospective research should be directed towards predicting those subgroups that are likely to benefit most from early tracheostomy.

\section{CONCLUSION}

In critically ill trauma patients, early tracheostomy was associated with shorter duration of mechanical ventilation, ICU and hospital LOS, and lower ventilation-associated 
pneumonia rates. In addition, total hospital costs were significantly decreased in the early tracheostomy group. In this cohort alone, early tracheostomy would have resulted in a potential hospital cost saving of 2.5 million/ year.

\section{REFERENCES}

1. Berlauk JF. Prolonged endotracheal intubation vs tracheostomy. Crit Care Med 1986 Aug;14(8):742-745.

2. Heffner JE. Tracheotomy application and timing. Clin Chest Med 2003 Sep;24(3):389-398.

3. Maziak DE, Meade MO, Todd TR. The timing of tracheotomy: a systematic review. Chest 1998 Aug;114(2):605-609.

4. Plummer AL, Gracey DR. Consensus conference on artificial airways in patients receiving mechanical ventilation. Chest 1989 Jul;96(1):178-180.

5. Heffner JE. Timing of tracheotomy in ventilator-dependent patients. Clin Chest Med 1991 Sep;12(3):611-625.

6. Lesnik I, Rappaport W, Fulginiti J, Wizke D. The role of early tracheostomy in blunt, multiple organ trauma. Am Surg 1992 Jun;58(6):346-349.

7. Rodriguez JL, Steinberg SM, Luchetti FA, Gibbons KJ, Taheri PA, Flint LM. Early tracheostomy for primary airway management in the surgical critical care setting. Surgery 1990 Oct;108(4):655-659.

8. Dunham CM, Ransom KJ. Assessment of early tracheostomy in trauma patients: a systematic review and meta-analysis. Am Surg 2006 Mar;72(3):276-281.

9. Major KM, Hui T, Wilson MT, Gaon MD, Shabot MM, Margulies DR. Objective indications for early tracheostomy after blunt head trauma. Am J Surg 2003 Dec;186(6):615-619.

10. Sugerman HJ, Wolfe L, Pasquale MD, Rogers FB, O'Malley KF, Knudson M, DiNardo L, Gordon M, Schaffer S. Multicenter, randomized, prospective trial of early tracheostomy. J Trauma 1997 Nov;43(5):741-747.

11. Kluger Y, Paul DB, Lucke J, Cox P, Colella JJ, Townsend RN, Raves JJ, Diamond DL. Early tracheostomy in trauma patients. Eur J Emerg Med 1996 Jun;3(2):95-101.

12. Bouderka MA, Fakhir B, Bouaggad A, Hmamouchi B, Hamoudi D, Harti A. Early tracheostomy versus prolonged endotracheal intubation in severe head injury. J Trauma 2004 Aug;57(2):251-254.

13. Ahmed N, Kuo YH. Early versus late tracheostomy in patients with severe traumatic head injury. Surg Infect (Larchmt) 2007 Jun;8(3):343-347.

14. Young D, Harrison DA, Cuthbertson BH, Rowan K; TracMan Collaborators. Effect of early vs late tracheostomy placement on survival in patients receiving mechanical ventilation: the TracMan randomized trial. JAMA 2013 May;309(20):2121-2129.
15. Koch T, Hecker B, Hecker A, Brenck F, Preuß M, Schmelzer T, Padberg W, Weigand MA, Klasen J. Early tracheostomy decreases ventilation time but has no impact on mortality of intensive care patients: a randomized study. Langenbecks Arch Surg 2012 Aug;397(6):1001-1008.

16. Alali AS, Scales DC, Fowler RA, Mainprize TG, Ray JG, Kiss A, de Mestral C, Nathens AB. Tracheostomy timing in traumatic brain injury: a propensity-matched cohort study. J Trauma Acute Care Surg 2014 Jan;76(1):70-76.

17. Rumbak MJ, Newton M, Truncale T, Schwartz SW, Adams JW, Hazard PB. A prospective, randomized, study comparing early percutaneous dilational tracheotomy to prolonged translaryngeal intubation (delayed tracheotomy) in critically ill medical patients. Crit Care Med 2004 Aug;32(8):1689-1694.

18. Rello J, Lorente C, Diaz E, Bodi M, Boque C, Sandiumenge A, Santamaria JM. Incidence, etiology, and outcome of nosocomial pneumonia in ICU patients requiring percutaneous tracheotomy for mechanical ventilation. Chest 2003 Dec;124(6):2239-2243.

19. Georges H, Leroy O, Guery B, Alfandari S, Beaucaire G. Predisposing factors for nosocomial pneumonia in patients receiving mechanical ventilation and requiring tracheotomy. Chest 2000 Sep;118(3):767-774.

20. Kollef MH, Von Harz B, Prentice D, Shapiro SD, Silver P, St John R, Trovillion E. Patient transport from intensive care increases the risk of developing ventilator-associated pneumonia. Chest 1997;112(3):765-773.

21. Ibrahim EH, Tracy L, Hill C, Fraser VJ, Kollef MH. The occurrence of ventilator-associated pneumonia in a community hospital: risk factors and clinical outcomes. Chest 2001 Aug;120(2):555-561.

22. Apostolopoulou E, Bakakos P, Katostaras T, Gregorakos L. Incidence and risk factors for ventilator-associated pneumonia in 4 multidisciplinary intensive care units in Athens, Greece. Respir Care 2003 Jul;48(7):681-688.

23. Alp E, Güven M, Yildiz O, Aygen B, Voss A, Doganay $\mathrm{M}$. Incidence, risk factors and mortality of nosocomial pneumonia in intensive care units: a prospective study. Ann Clin Microbiol Antimicrob 2004 Sep 15;3:17.

24. Nseir S, Di Pompeo C, Diarra M, Brisson H, Tissier S, Boulo M, Durocher A. Relationship between immunosuppression and intensive care unit-acquired multidrug-resistant bacteria: a case-control study. Crit Care Med 2007 May;35(5):1318-1323.

25. Möller MG, Slaikeu JD, Bonelli P, Davis AT, Hoogeboom JE, Bonnell BW. Early tracheostomy versus late tracheostomy in the surgical intensive care unit. Am J Surg 2005 Mar; 189(3):293-296.

26. Meng L, Wang C, Li J, Zhang J. Early vs late tracheostomy in critically ill patients: a systematic review and meta-analysis. Clin Respir J 2015 Mar 12. 


\section{Early Tracheostomy (ET): Not Just Financial Implications}

Despite the increasing number of studies including several randomized control clinical trials comparing early $v s$ late tracheostomy, there continues to be a perplexing lack of specific recommendations when trying to answer the following 'simple' question: Should we perform a tracheostomy on this patient?

The results presented in this manuscript confirm findings from preview retrospective studies, showing that patients who undergo ET in this case defined as less than 7 days have a reduced number of day in the ventilator, reduced rate of VAP, reduced length of stay both in the ICU and the hospital and, as expected, this reduction translated in decreased hospital cost. Unfortunately, this study does not help us answering the question formulated above and does not confirm the results from evidence-based medicine data available from most recent RCT studies on the issue of timing of tracheostomy. Nevertheless, the authors recommend, that if a patient's anticipated ventilator course will require more than 21 days then an ET should be performed as soon as possible. How can we predict on day 3 or 7 whether the patient will remain intubated by day 21 remains a great challenge however.

From the evidence currently available in the literature, clinicians have learned one thing: a significant number of ventilated patients deemed to require a tracheostomy within the next 10 days may end up being separated from the ventilator in $55 \%$ of the cases. ${ }^{1}$ This means that there is a 50/50 chance of being wrong when trying to decide not just who needs a trach but how much longer should we wait before submitting the patient to a procedure that may not be necessary (should we have waited long enough). No wonder current evidenced based medicine data cannot fully answer these complex set of circumstances.

The reader should go back and analyze the data of this current publication from a practical view point; the majority of patients benefiting from ET in this retrospective review were multiple injured individuals with evidence of TBI and a GCS $<$ than 8 . This finding confirms previous observations made in this population and suggest a favorable role for ET in head injured patients. ${ }^{2}$ No further attempt to generalize these finding should be made.

There are recent editorials, several systematic reviews, including a Cochrane publication and a meta-analysis all dealing with the issue of timing of tracheostomy. ${ }^{3-5}$ The current recommendations from all these publications is that when ET is studied among all patients on mechanical ventilation, ET showed no significant difference in clinical outcomes compared to that of patients undergoing prolonged intubation and all recommend that more rigorously designed and adequately powered RCTs are required to confirm these findings. The Cochrane review indicates that the evidence is considered to be of moderate quality but is not more than suggestive of recommending early (as against late) tracheostomy for reducing mortality among critically ill patients on prolonged mechanical ventilation. However, the available evidence should be considered with caution, information is insufficient to permit conclusions about any subgroup or individual characteristic(s) potentially associated with the best indications for early or late tracheostomy because clinical heterogeneity is a characteristic inherent to patients in the ICU. ${ }^{5}$

In my opinion, it is not feasible, nor appropriate to compare all patients on MV and their indications for tracheostomy in a single large RCT. The underlying conditions for which a patient is requiring a prolonged intubation in any given time are remarkably different among ICU patient population. A medical ICU with a large percent of chronic pulmonary disease patients will have a population of individuals not all comparable with those in a polytrauma ICU or within a neurotrauma ICU. Should we then be surprised when despite the availability of some EBM class I data from several controlled clinical trials performed so far ${ }^{1,6,7}$ we still get controversial results?

To simply suggest that we should adopt a 'wait and see' strategy for at least 10 days is also as unreasonable as to expect that this mixed bag of respiratory failure patients are included in a single clinical trial in order to answer this very same question: Should we perform a tracheostomy on this patient?

\section{REFERENCES}

1. Young D, Harrison DA, Cuthbertson BH, Rowan K. Effect of early vs late tracheostomy placement on survival in patients receiving mechanical ventilation: the Tracman randomized trial. JAMA 2013 May 22;309(20):2121-2129.

2. Alali AS, Scales DC, Fowler RA, Mainprize TG, Ray JG, Kiss A, de Mestral C, Nathens AB. Tracheostomy timing in traumatic brain injury: a propensity-matched cohort study. J Trauma and Acute Care Surg 2014 Jan;76(1):70-76.

3. Huang H, Li Y, Ariani F, Chen X, Lin J. Timing of tracheostomy in critically ill patients: a meta-analysis. PLoS One 2014 Mar 25;9(3):e92981.

4. Angus DC. When should a mechanically ventilated patient undergo tracheostomy? JAMA 2013 May 22;309(20):2163-2164. 
5. Andriolo BN, Andriolo RB, Saconato H, Atallah AN, Valente O. Early versus late tracheostomy for critically ill patients. The Cochrane database of systematic reviews 2015 Jan 12;1:CD007271.

6. Terragni P, Mascia L, Faggiano C, Tenaglia T, Morello E, Succo G, Ranieri M, Brazzi L. A new training approach in endoscopic percutaneous tracheostomy using a simulation model based on biological tissue. Minerva Anestesiologica (2015) 1 Minerva Anestesiol. Minerva Anestesiol 2015.

7. Griffiths J, Barber VS, Morgan L, Young JD. Systematic review and meta-analysis of studies of the timing of tracheostomy in adult patients undergoing artificial ventilation. BMJ 2005 May 28;330(7502):1243.

Jaun Carlos Puyana

Professor, Department of Surgery University of Pittsburgh, Pittsburgh, USA 